\title{
Effective leadership, management and supervision in health and social care (3rd ed.)
}

\author{
Richard Field and Keith Brown (Eds.) \\ Sage, London, 2020 \\ ISBN 978-1-5264-6840-6, pp.213, paperback, approx. NZD40.00
}

Kia ora koutou! Ko Parehaka tē Maunga

Ko Hatea tē awa

Ko Pākehā tē iwi

Ko Tangiteroria te hapori

Ko Emerge Aotearoa te māhī

Ko Diane āhau

I was attracted to read this book as I am in a role where I am managing two small teams within a mental health residential setting. I am a registered social worker and I have been working as such since 2001. I have predominately worked across health services. This is my first management position, and I was briefly in a mental health professional role which also required some coaching and mentorship. I have previously competed a postgraduate Diploma of Social Services Supervision at Massey University (grad 2014) and this year I also have attended two full days of leadership training in my organisation. My first impressions were that this book led on from these learnings and strengthened my understanding in both leadership models and practice.

This book is based on an English health and social service system where the focus is on the wellbeing of older people. However, I believe that there are similarities in the issues discussed, both here and in the UK. The main one being: the helping professions and this field of practice bring multiple challenges, in particular, resourcing and complex presentations of those people we work with. I found the book to be easily read. It outlines clearly its objectives, uses simple language, and it poses questions for review within each chapter. This book has two editors, who have included a crosssection of views including chapters from a nurse consultant, a specialist in leadership development an event facilitator, a researcher and a social work consultant. This is the 3 rd edition.

The introduction of the book discusses some basic assumptions including what leaders do and how they do things is important. Selfleadership is a concept I first heard this year, but on reflection I have been practising for a long time. On a personal level, it is about continual learning, both in professional and personal worlds. In a management context, it is about getting the team to also engage, so they aren't doing just the "basics" but that the work is almost a cross-over into their own life journey, "all development activity should be an opportunity for both personal and organisations growth leading to better outcomes for patients, service users, staff and other stakeholders" (Field \& Brown, 2020, p. $\mathrm{xv}$ ). Supervision is identified as a key tool along with a management style which is authentic. There is also a focus that staff need both challenges and support to be effective workers.

There are 12 chapters after the Introduction. These are: Context; Leading services and care for older people; Self- 
leadership; Developing your leadership style; Supervision; Leading successful teams in health and social care; Strategic thinking, commissioning and planning; Effective budget management; Leading the workforce for health and social care services for older people; Impact evaluation of leadership programmes; Developing collaborative skills; and Further key theoretical perspectives.

The structure of the book also is easily engaged with. Each chapter begins with "Chapter outcomes" and it is anticipated that you will understand the concepts outlined here by the end of the chapter. Next in each chapter is an introduction, then the development of concepts and ideas. The review/ reflection points are included in this part of the discussion. The chapters then end with key learnings. As well, the book offers case study in practice; you do not have to work with the elderly to get a lot out of the book. I thought the concepts linked well with my field of practice, mental health, and more recently, mental health with adults and older people.

I thought this book was well worth a read. There are some significant challenges in making the time, and then being able to realistically implement the learnings. This is a challenge always! I think the authors do a pretty good job of holding a balance of practical interventions and helping us to think about what is practical. I do think you could use this book to just look at chapters which you need at the time. For example, self-leadership is a concept I am relatively new to, so it was great to read and extend my understanding on that. However, the chapter on budgets I am not quite ready for (and also am not really in control of yet) so I could scan this, but focus on the things I was more interested in. 